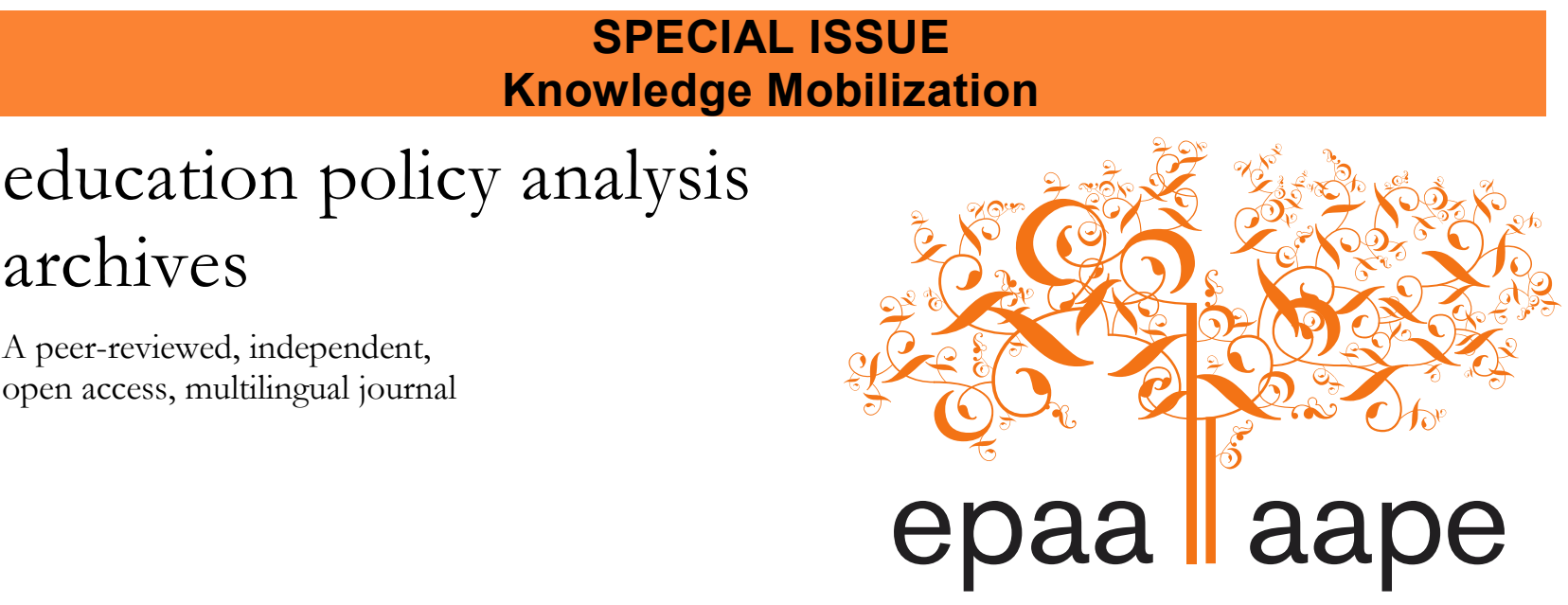

Arizona State University

ISSN 1068-2341

\title{
Looking Outside Education: \\ Expanding Our Thinking about Moving Research into Practice
}

\author{
Jack Schneider \\ College of the Holy Cross \\ United States
}

Citation: Schneider, Jack. (2015). Looking outside education: Expanding our thinking about moving research into practice. Education Policy Analysis Archives,

23(119). http://dx.doi.org/10.14507/epaa.v23.1966

This article is part of EPAA/AAPE's Special Issue on Knowledge Mobilization Guest Co-Edited by Dr. Amanda Cooper and Samantha Shewchuk.

\begin{abstract}
This essay explores the usefulness of looking outside of education for inspiration, particularly with regard to seemingly intractable issues that have been resigned to the margins. First, it proposes that, rather than comparing education to medicine and law - the traditional comparison fields for education-we turn instead to the "helping fields" of nursing and social work, which seem to offer better parallels. Then it considers a test case: the stalled conversation around linking research and practice in education. Finally, the work offers a model framework of the sort that might be generated through such cross-field analysis-one for organizing our thinking about what matters in moving research into practice in education.
\end{abstract}

Keywords: research; practice; social work; nursing; scholarship; reform. 


\section{Buscando fuera del ámbito educativo: Ampliando nuestro pensamiento sobre la movilización de la investigación a la práctica}

Resumen: Este ensayo explora la utilidad de buscar inspiración fuera del ámbito educativo, en particular con respecto a cuestiones aparentemente insolubles que se han marginalizado. En primer lugar, se propone que, en lugar de comparar la educación con la medicina y los abogados -campos de comparación tradicionales para la educación- miremos en lugar a los "campos de ayuda" como la enfermería y el trabajo social, que parecen ofrecer mejores paralelos. En segundo lugar se considera un caso de prueba: la conversación estancada en torno a la vinculación de la investigación y la práctica en educación. Por último, el trabajo ofrece un modelo de marco conceptual que pudiera generarse a través de los cruces entre campos de análasis -uno para organizar nuestro pensamiento acerca de lo que importa en la movilización de la investigación a la práctica en educación.

Palabras clave: investigación; práctica; trabajo social; enfermería; investigación; reforma.

\section{Buscando fuera del ámbito educativo: Ampliando nuestro pensamiento sobre la movilización de la investigación a la práctica}

Resumen: Este ensayo explora la utilidad de buscar inspiración fuera del ámbito educativo, en particular con respecto a cuestiones aparentemente insolubles que se han marginalizado. En primer lugar, se propone que, en lugar de comparar la educación con la medicina y los abogados -campos de comparación tradicionales para la educación- miremos en lugar a los "campos de ayuda" como la enfermería y el trabajo social, que parecen ofrecer mejores paralelos. En segundo lugar se considera un caso de prueba: la conversación estancada en torno a la vinculación de la investigación y la práctica en educación. Por último, el trabajo ofrece un modelo de marco conceptual que pudiera generarse a través de los cruces entre campos de pensamiento -uno para organizar nuestro pensamiento acerca de lo que importa en la movilización de la investigación a la práctica en educación.

Palabras clave: investigación; práctica; trabajo social; enfermería; investigación; reforma.

\section{Introduction}

Looking outside of education is a notoriously thorny enterprise-often more problematic than helpful. As a result, those working in the field have rightly grown skeptical of such comparative thinking (Labaree, 2000; Maxwell, 2015).

Yet the usefulness of drawing comparisons with other fields is in large part dependent on their comparability. Some professions, after all, share key characteristics that others do not. Law and medicine, for instance, are more like each other than they are like education. And, as this essay argues, the cluster of fields generally known as the "helping professions" (Boehm, 1958; May, 1939) — nursing and social work, among them — may make for much better comparison cases. Thus, although they may not offer concrete lessons, they may at least not be dismissed as irrelevant.

Of course, the usefulness of comparative thinking is also dependent on the purpose for which it is being deployed. It may be more productive to look outside a field, for instance, when particular lines of conversation within that field have stalled or grown tired. In such instances, looking to reasonably comparable fields can foster more imaginative thinking about future possibilities. Again, the practice may not generate explicit instruction about what to do in education. But by offering fresh perspective, it may help us to see the field of education in new light.

This essay has two purposes. The first is to propose that the helping professions of nursing and social work may be more useful, if still imperfect, comparison fields for education, at least in the United States. The second purpose of the work is to offer an example of how looking at those fields 
might expand and inspire our thinking. Specifically, the essay considers a notoriously troubling issue - that of moving research into practice — and shows how looking across fields might foster creative thinking. It concludes by offering a model framework for organizing our thoughts about closing the gap between scholars and teachers.

\section{A Stalled Conversation}

For decades, educational research has had a troubled relationship with practice (Kaestle, 1993; Wolk, 2007). One explanation for this is that a significant amount of research is simply irrelevant for classroom use. Yet it remains the case that even those research concepts that are relevant for practice have generally failed to penetrate the classroom-a fact that scholars have spent a great deal of time and energy explaining. The teaching profession, they have argued, is simply not culturally or structurally positioned to absorb educational research (Cohen, 1990; Schneider, 2014). Teachers are not trained to scrutinize scholarship (Cochran-Smith \& Lytle, 1999; Zeuli, 1994). Teachers face major time constraints and have little time to meet together (Miller, Drill, \& Behrstock, 2010; National Education Association, 2010). And teachers tend to be given sporadic and inconsistent professional development (Guskey, 2000; Hill, 2009). Consequently, the divide between the worlds of research and practice, whatever the intentions of scholars, has seemed impossible to negotiate.

It may come as no surprise, then, that scholars are often the first to disengage from conversations about linking research with practice in education (Kennedy, 1997). They know from experience that the two worlds cannot be easily brought together. The work of their peers has helped explain why. And many of the recommendations for improving the situation entail reforms that are unlikely to be undertaken (e.g. Burkhardt \& Schoenfeld, 2003).

As a result of all this, thinking about the relationship between research and practice can be relatively gloomy and uninspired business. Thus, if we are to have more robust and imaginative conversations about connecting research with practice, it may be necessary to look at models of success outside of education to spur thinking and organize ideas.

\section{The Theoretical Comparability of the Helping Fields}

Looking for inspiration outside the field of education is a relatively common occurrence (Berliner, 1990; Neville, Sherman, \& Cohen, 2005; Welker, 1991). Occasionally, such efforts have even been fruitful-shining new light on the nature of teaching and learning, as well as on how to improve them (Shulman, 2005). Yet comparisons have most frequently been made with professions like medicine and law-professions which, while different enough from education to be interesting, may be too different to be of value. In fact, such cases can underscore fundamental occupational differences, reinforcing the notion that education is uniquely burdened in particular matters-like the divide between research and practice. They can often inspire disillusionment, bringing conversations to a quick close.

Turning to helping fields like nursing and social work, however, might make for a more profitable enterprise. Though distinct in their own right, such fields share with education many of the characteristics that influence how practitioners engage with scholarship. The fields are similar across core professionalization criteria like licensing, control over training, and authority over decision-making (Bureau of Labor Statistics; Center for Workforce Studies, 2006; National Education Association, 2010). Like teachers, social workers and nurses are predominantly women, earn roughly the median household income for the U.S., and have middling status (Abbott \& Meerabeau, 1998; Etzioni, 1969). They possess similar levels of education-with some specialized training, but not more than their salaries can justify. Their work is oriented toward human improvement, and professionals in each field are dependent upon client cooperation for success 
(Cohen, 2011; Jenny \& Logan, 1992; Popple, 1985). They spend the bulk of their workdays interacting with clients, limiting opportunities for professional growth. And they have a level of professional autonomy without significant power to shape the nature of their work (Abbott \& Meerabeau, 1998; Ingersoll, 2003; Ingersoll \& Perda, 2008). Insofar as this is the case, then, professionals in all three fields theoretically face similar limits with regard to their ability to engage with research. Given these similarities, the helping professions may be more relevant as comparison cases for education, at least if the aim is to gain fresh perspective on old problems-problems like the gap between research and practice.

\section{The Comparability of Nurses}

The field of nursing parallels that of education in a number of significant ways. There are many pathways into each profession, but all require specialized training and licensing. The work of nurses and teachers is often perceived as a kind of content delivery — drugs for nurses, curriculum for teachers - yet they perform a broad range of professional tasks. And although professionals in each field are overseen by others, their work also requires a substantial amount of independent reasoning and judgment-in the case of nurses, about the progress of patients and the effectiveness of their received care.

The two professions also parallel each other with regard to the relationship between research and practice. Like teaching, nursing is characterized by a number of barriers separating scholars and practitioners. So, although nurses are expected to engage in continuing education, they also face many of the same challenges as teachers in trying to identify research that is of value to their practice. One study, for instance, indicated that research reports are not readily available to nurses and that relevant literature is often not compiled in one place (Paramonczyk, 2005). And according to another study, understanding statistical terms and specialized jargon is a particular challenge for nurses untrained in deciphering medical research (Majid et al., 2011). As such, despite the fact that much of medical research is practice-oriented, the effectiveness with which those findings are conveyed and transmitted can vary dramatically.

Somewhat surprisingly given their generally favorable stance toward science, nurses can also approach research with a degree of skepticism. At the root of this is the fact that nurses, like teachers, tend to possess a particular set of characteristics connected to their class, training, and daily work (Bureau of Labor Statistics; U.S. Department of Labor). Consequently, nurses often share a common core of interests, anxieties, attitudes, and values that many non-nurses are unaware of and fail to tap into. As one set of scholars found, nurses will often recognize the academic credentials of research authors, yet reject them as not credible for their lack of clinical experience, their distance from patients, and their status as "non-nurses" (McCaughan, Thompson, Cullum, Sheldon, \& Thompson, 2002).

Nurses also face significant constraints associated with the structure of their occupation. Like teachers, they have little down time during the day and have few opportunities to familiarize themselves with research (Paramonczyk, 2005; Pravikoff, Pierce, \& Tanner, 2003). Additionally, their work tends to be measured in "tasks" completed rather than in the development of new approaches to the work itself (Young, 2003). Thus, while hospitals seeking to orient their nurses toward research increasingly offer in-service training in "evidence-based practice," the scattershot nature of such programs tends to produce only mixed results. In part, this is due to the fact that theoretical knowledge may not usually, or even often, be applicable in predicting or explaining complex interactions in a social field (Heggen, 2008). Yet it is also clear that, even when nurses do see research as important to their practice, they often fail to take advantage of resources like in- 
house libraries or electronic databases because of the occupational constraints they face (BekeHarrigan, Hess, \& Weinland, 2008).

Finally, nurses are isolated from research because they operate without robust supports for communication. Like teachers, nurses often turn to each other for professional advice. Yet their interactions are constrained by factors like time, workload, and task orientation. And though they often share similar responsibilities, knowledge transmission is complicated by the fact that nurses work in separate organizations, even when working within a single hospital (Addicott, McGivern, \& Ferlie, 2006). When they do have an opportunity to share knowledge with each other, it is often related to a practical skill, or to knowledge that takes the form of a heuristic (Fisher \& Fonteyn, 1995).

On the whole, then, nurses approach research much the way that teachers do. Like teachers, they maintain a significant interest in research, and are deeply concerned with helping their patients. Yet the field is marked by several of the same challenges that prevent research from entering practice in education. Nurses generally do not receive training and support to decipher research; they can maintain a philosophical bias against it; they face serious occupational constraints; and they face significant challenges trying to communicate with each other.

\section{How Nurses Connect with Research}

When it comes to connecting with research, nurses face significant challenges not entirely unlike those faced by teachers. Despite those challenges, however, a number of policies and practices have begun to make research more accessible to nurses.

Many hospitals have helped nurses connect with research by taking the very straightforward step of making it available. Access to databases, training in use of them, and institutional directives to consult research have helped many nurses locate relevant scholarship (Pravikoff, Pierce, \& Tanner, 2003). Another promising practice has been the development of research committees, organized by clinic or by nursing unit, which share research with staff and promote practitionerresearch. In larger teaching hospitals, many such committees sponsor research, encourage nurses to conduct their own studies, and help staff attend professional conferences. The result of such practices, while not uniform, has been an uptick in the capacity and willingness of nurses to engage with scholarship.

In addition to making research more visible to nurses, a number of practices have fostered a positive orientation toward research to make its use more acceptable in practice. One interesting model, for instance, is the "Magnet" designation offered by the American Nurses Credentialing Center-a distinction earned by roughly seven percent of registered hospitals (American Nurses Credentialing Center). The credential recognizes organizations for excellence in nursing, with a particular emphasis on continuing education, as well as on the use of research in practice. Hospitals seeking the designation are encouraged to structure opportunities for discussion and learningthrough the sharing of exemplars from other Magnet facilities, through interactions with industry experts, and through dissemination of current research findings.

Recent developments in pre-service training programs have also begun to address the challenge of connecting practitioners with research. Increasingly, graduate programs are oriented toward research-informed practice, either through particular courses or through the integration of such practice across the curriculum (Melnyk, Fineout-Overholt, Feinstein, Sadler, \& GreenHernandez, 2008). And in a similar vein, a new kind of formal pathway has been conceived as a means of training nurses to function as intermediaries between the worlds of research and practice. That pathway - the doctoral degree in nursing practice, endorsed by the American Association of Colleges of Nursing (2012)—specifically targets nurses seeking a terminal degree, offering "an 
alternative to research-focused doctoral programs." Ultimately, the aim of such a program is that graduates will be "well-equipped to fully implement the science developed by nurse researchers" (American Association of Colleges of Nursing, 2012).

Much has also been done in terms of making research usable for nurses, who face serious constraints on their time and who may struggle to see research findings as feasible. Many hospitals, for instance, have hired medical librarians whose responsibilities include work with nurses. While the quality of libraries and staff certainly varies, nursing researchers have shown that engaged health sciences librarians can be key drivers in helping nurses stay abreast of research developments (Krom, Batten, \& Bautista, 2010). Those seeking to make research usable have also worked to establish frameworks like the Iowa Model of Evidence-Based Practice to Promote Quality Care. This protocol for nursing practice requires the formation of teams to review relevant research, synthesize it for practice, and help disseminate results (Titler et al., 2001).

Finally, efforts have been made to increase the transportability of research by connecting nurses with each other, both within and across units and hospitals. Researchers, for instance, have detailed the promise of collaborative workgroups, like journal clubs, in which nurses meet to discuss the use of research in practice. And there is substantial evidence that such clubs improve researchcritiquing skills and increase the dissemination of research findings, though their success in integrating evidence into practice is dependent on the skills of facilitators (Lizarondo, GrimmerSomers, Kumar, \& Crockett, 2012).

Nursing, of course, is different than teaching. Nurses work with a different clientele, in different settings, for different reasons. They receive different training, and they possess different competencies. Yet there are clear similarities between these fields, with practitioners working in zones of uncertainty to assist clients upon whom they are dependent for success. And though efforts to connect research with practice in nursing are imperfect, and not always applicable to education, they nevertheless provoke thought about how teachers and educational researchers might more consistently engage with each other.

\section{The Comparability of Social Workers}

Social work, another of the helping professions, provides a second parallel for exploring the relationship between scholarship and practice. Like nurses and teachers, social workers engage in complex work, which is at its core a relational enterprise in which they must consistently make judgments - about the safety of a child, for instance, or the mental health of an elder —and encourage client cooperation.

Leaders in social work have placed increasing emphasis in recent years on the use of research. According to the National Association of Social Workers (2008), caseworkers should "critically examine and keep current with emerging knowledge relevant to social work" (p. 25), making sure to "fully use evaluation and research evidence in their professional practice" (p. 25). This kind of professional standard is relatively new to the field, and is a response to the historical tendency among social workers to value experience and anecdote over scholarly research (Sheldon \& Chilvers, 2002). Realizing this aim, however, has not been simple, and has manifested in a wide range of efforts to encourage the use of research in social work practice.

One clear obstacle to research-informed practice is the inaccessibility of scholarship. At the most basic level, many practitioners do not have access to subscription-based journals and databases (Mullen, Bledsoe, \& Bellamy, 2008). Even if they did, however, the field has traditionally been characterized by low levels of capacity for vetting research. In one survey, for instance, 56 percent of respondents indicated that they had not been trained to apply research findings to practice and 65 
percent indicated that they had not been trained to interpret research (Booth, Booth, \& Falzon, 2003). Perhaps even more problematically, this lack of training can lead to a feeling of inefficacy with regard to distinguishing high-quality research from low. In a 2011 survey, more than 60 percent of graduate students in social work responded that research made them "anxious" (Morgenshtern, Freymond, Agyapong, \& Greeson, 2011). Another study indicated that social workers frequently felt unable to critically appraise the evidence base (Bilsker \& Goldner, 2004).

Social work also continues to be shaped by professional structures that emphasize "action over reflection" and "productivity over quality" (Booth et al. 2003, p. 193; Rubin \& Parrish, 2007, p. 193). This is often combined with a sense among some social workers that research is mechanistic and cold, generating suspicion and distrust (Bellamy, Bledsoe, \& Traube, 2006; Rubin \& Babbie, 2011). As such, research can often seem philosophically incompatible with practice. The result is that social workers often prefer "guidelines that represent professional consensus rather than research evidence" (Mullen \& Bacon, 2004, p. 18).

Time and support—or lack thereof-represent another set of significant obstacles for those seeking to connect research with practice. Social workers, for instance, tend to report heavy caseloads that are often characterized by a wide range of client problems and accompanying paperwork (Booth et al., 2003; Center for Workforce Studies, 2006). Thus, like teachers and nurses, they generally have little time for engaging with research. And, as is often the case in education and nursing, the impact of such time constraints is compounded by what many see as insufficient support for applying research findings (Sheldon \& Chilvers, 2002).

Finally, because of the tremendous diversity that characterizes social work, research is difficult to transmit across more than a fraction of the profession. Social workers practice in a wide variety of subfields — mental health, aging, child welfare — and they work in a broad range settings: community centers, schools, hospitals, and social service agencies. Consequently, it can be difficult to say anything in general about how to best serve clients. This, of course, only reinforces cultural uncertainty in the profession about the usefulness of research.

\section{How Social Workers Connect with Research}

Despite these less than ideal conditions for moving research into practice, there are some significant developments that have strengthened the connection between scholars and social workers-developments worth taking note of, even if the field is still plagued by disconnects. One key step in this process has been the generation of momentum behind a common aim. Evidencebased practice is perhaps the most visible manifestation of this increasingly general concern with linking the worlds of research and practice. And though not all scholars support that particular model, many alternatives nevertheless seek to foster a stronger connection between the two spheres (Gibbs, 2003; Mullen, Bledsoe, \& Bellamy, 2008).

A common aim alone is obviously not sufficient to link social workers with scholarship. After all, the professional attitudes and aptitudes of social workers must be addressed if research is to achieve a life in practice. Insofar as that is the case, one lever for change has been pre-service training in bachelor's and master's degree programs. The latest Educational Policy and Education Standards from the Council on Social Work Education (2008) in the U.S., for instance, states clearly that future social workers should "use practice experience to inform research, employ evidencebased interventions, evaluate their own practice, and use research findings to improve practice, policy, and social service delivery" (p. 5). And though this is simply a policy statement, there is some evidence that it is being taken seriously. Many programs have created new courses designed to make research more visible and to help students "evaluate research articles ... with a more discerning eye" 
(Grinnell \& Unrau, 2010, p. 5). And according to one study, as social workers began to view research as accessible, they gained interest in it and confidence in using it (Lundahl, 2008).

Particular efforts have also cultivated among social workers the view that research is an acceptable, and even valuable, aspect of practice. Pre-service training has helped with this not only by increasing capacity to engage with research, but also by explicitly framing research as useful to practice (Jensen, 2007). Professional organizations like the National Association of Social Workers have played a role, endorsing research-informed practice. And for their part, social work agencies have shown evidence of being able to change practitioner views toward research, primarily through collaborative partnerships with scholars (Bellamy, Bledsoe, Mullen, Fang, \& Manuel, 2008). Once in the field, social workers still face significant feasibility constraints-engaging in complex, casespecific work, and doing so with little time to consult scholarship. But they also increasingly operate with more tools at their disposal. Volumes like the Social Workers' Desk Reference (Roberts \& Greene, 2002), for instance, function as important resources for practitioners-translating research methods and findings for use in the field. Professional organizations like the Society for Social Work and Research have played a role in adjusting scholarship for practice by working to advance, disseminate, and translate social work research (Rubin \& Parrish, 2007). And groups like the Campbell Collaboration conduct systematic reviews and meta-analyses of social interventions, making it possible to read research by topic rather than by individual study.

Finally, the relationship between research and practice in social work has been strengthened by efforts to promote collaboration and exchange. One model for increasing the transportability of research is the "university-agency" model, which aims to foster connections between scholars and practitioners by creating formal partnerships between their organizations. Additionally, the model reconfigures the social work agency, situating it not just as a provider, but also as a learning community (Bellamy et al., 2008). Other models have sought to link agencies with each other, or to organize social workers into teams (Edmondson, Bohmer, \& Pisano, 2001). And still others have positioned "knowledge brokers" as intermediaries in the process (McNeill, 2006). In all cases, however, the central principle is that knowledge dissemination is contingent not merely upon access to research, but also upon access to other professionals who use scholarship to inform their work. As is the case in nursing, research and practice in social work often remain isolated in separate spheres. Neither profession has solved the problem. And even if they had, any lessons that might be gleaned from promising practices in nursing and social work would have to be adapted for the specific context of K-12 classrooms if they were to apply to education.

Still, a look at these other professions does offer valuable new perspective. First, it reveals that although the challenge of moving research into practice in education is a particular problem, it is not an entirely unique one. And second, when we look across multiple fields-even if we do not do so in great depth or detail—we may begin to focus more on underlying concepts or structures that might stimulate new ways of thinking about seemingly intractable issues.

\section{Food for Educational Thought}

Because these three helping professions share a number of important characteristics, it is possible to make the case that the work of these fields can be mutually informative. This, again, would not be true for the comparison of any set of professions for any particular reason. As scholars in education are all too aware, comparisons between teachers and doctors-made primarily in the context of arguments for the professionalization of teaching — can be more distracting than helpful (Hammersley, 1997). There are simply too many cultural and structural differences between the 
professions to conduct any kind of substantial comparative analysis, and the comparison often reflects wishful thinking about the nature of education (Labaree, 1992).

But while it is difficult to picture teachers attending graduate programs for four years and then spending three to six years in clinical residencies, as doctors do, it is easier to imagine many of the moves that have been made in nursing and social work. And though the similarities with teachers are in some ways stronger among social workers, who have a great deal of discretion as "street-level bureaucrats" (Lipsky, 1980), they are stronger in other ways among nurses, who operate in an ever-changing policy environment. Generally, then, we might conclude that the context is similar enough that drawing such comparisons is at least not immediate cause for argument. It is even possibly helpful.

Again, the usefulness of such comparative thinking is not that it offers discrete lessons, or that it highlights practices completely unknown in the field of education. Rather, its potential utility is for stimulating new perspectives - by highlighting the essential value of work already being done at a small scale, or by generating new models for supporting our thinking.

The framework below is one such example. Synthesizing notable examples from several fields, it shifts focus away from individual programs - programs which, though interesting, are largely disconnected from each other, as well as from a more coherent vision. Instead, it focuses our attention on the bigger picture-in this case, factors that appear to be particularly influential in shaping a research-to-practice pipeline in relatively similar professions. And though such a framework is, by nature, a kind of conjecture, such models may ultimately be more useful in helping us imagine education-specific policy adjustments, as well as in cultivating new perspectives on existing systems and structures (Table 1):

Table 1

Key Factors in Shaping the Movement of Research into Practice

\begin{tabular}{ll}
\hline Factor & Definition \\
\hline Visibility & $\begin{array}{l}\text { Research is accessible to working teachers and its quality can be determined } \\
\text { by them. }\end{array}$ \\
Acceptability & $\begin{array}{l}\text { Research is understood as valuable by teachers and is compatible with their } \\
\text { professional worldview. }\end{array}$ \\
Feasibility & $\begin{array}{l}\text { Research has practical applications that do not require a dramatic overhaul of } \\
\text { the profession. }\end{array}$ \\
Transportability & $\begin{array}{l}\text { Research, as well as teacher views on that research, can be easily shared across } \\
\text { classrooms and organizations. }\end{array}$ \\
\hline
\end{tabular}

A model like this, produced by looking across fields, might spark new ideas about linking research with practice in education. And, equally important, it might help us organize ideas, whether old or new, as part of a broader and more coherent vision. In short, such efforts might expand our sense of the possible.

Considering the importance of visibility, for instance, we might imagine the U.S. Department of Education creating a more usable database than either the Educational Resources Information Center (ERIC) or the What Works Clearinghouse-one that is focused on practice, organized by grade and subject, professionally vetted, and adapted to use in classrooms. Or we could imagine them asking university-led groups to engage in such work, as has been the case with the National Clearinghouse for History Education. We might imagine states creating the equivalent of nursing's Magnet designation - indicating a focus on utilizing research in "laboratory" schools. Scholars might take steps to foster connections with practice by writing in new venues, creating open-access 
versions of journal articles, and translating their work for practitioners. Or they might collaborate on publications equivalent to the Social Workers Desk Reference-research-based volumes specifically targeted at K-12 practitioners, and which could be organized by priority area. The point of this exercise is not to describe all the possibilities. Nor is it to generate exclusively "new" ideas (models like the laboratory school are hardly novel). Instead, the point is to illustrate the degree to which we might approach an old problem with a fresh perspective.

Considering the issue of acceptability, we might imagine an equally broad range of possibilities. Teacher education programs might make training in the consumption of research a part of standard teacher preparation. Accrediting bodies like NCATE might support such efforts by establishing a framework for research-informed practice, not unlike the Iowa Model in nursing, or by creating a designation for approved programs. And looking beyond teacher licensure programs, colleges of education might also consider overhauling the Doctorate in Education as a degree for those interested in helping schools connect with research-another old idea that might gain renewed momentum if presented as a part of an overarching vision related to bridging the gap between research and practice.

Considering the importance of feasibility, we might continue to add to the list. Districts, for instance, might hire research librarians charged with collecting, reviewing, synthesizing, and disseminating relevant scholarship. Unlike district research offices, which are often housed in assessment departments and oriented toward collecting data, research libraries and their staff would be trained for and charged with the specific aim of directing teachers to research. For their part, scholars might consider "translating" their work for practice, much as the Stanford History Education Group has done-creating a research-based curriculum that, to date, has been downloaded over a million times (https://sheg.stanford.edu/). Alternatively, educational researchers might seek to create a version of social work's university-agency model. Or they might work through models like the Strategic Education Research Partnership (http://serpinstitute.org/), sponsored by the National Academy of Education to foster stronger relationships with the world of practice. Whatever the approach, an emphasis on the concept of feasibility-a concept that also appears critical in bridging research with practice in other fields - seems essential.

Finally, we might reimagine the research-to-practice pathway by concentrating on the issue of transportability. Policymakers and school administrators might support teachers in the establishment of journal clubs, something many nurses have done to great success. Or they might help establish collaborative research committees at the school level the way that some social work agencies, and indeed, some school districts, have done. Similarly, educators might make a more compelling case for the importance of the lesson study model-small groups of teachers meeting regularly over the course of several weeks to investigate a topic, often with the assistance of an expert-by articulating the work as a crucial component of a larger process. We might even imagine social networks and online communities playing an important role in promoting the transportability of research.

To repeat: many of these ideas already exist in some form. Although looking across fields can generate new ideas, the more valuable contribution may actually be in seeing old ideas in a new light—viewing them not as isolated cases, but as a part of a broader and more coherent vision. In other words, looking to other fields is important not because it offers solutions, but because it can cultivate new ways of seeing. And that is particularly useful in the case of longstanding and seemingly intractable problems - problems like that of trying to link the worlds of research and practice.

Looking across relevant professional fields, like nursing and social work, is hardly a panacea. How could it be, when those fields have much to do, themselves, if they wish to close the gap 
between research and practice? Still, in a field where so many have given up all hope of linking the worlds of scholarship and practice, considering cases from other professions might just be enough to convince a new generation of scholars that the task is worth the struggle. They might even decide to give the problem some thought.

\section{References}

Abbott, P., \& Meerabeau, L. (1998). The sociology of the caring professions. New York, NY: Psychology Press.

Addicott, R., McGivern, G. \& Ferlie, E. (2006). Networks, organizational learning and knowledge management: NHS cancer networks. Public Money and Management, 26(2), 8794.

American Association of Colleges of Nursing. (2012). DNP fact sheet, 2012. Retrieved from http://www.aacn.nche.edu/media-relations/fact-sheets/dnp

American Nurses Credentialing Center. Find a magnet hospital. Retrieved from: http://www.nursecredentialing.org/findamagnethospital.aspx

Beke-Harrigan, H., Hess, R., \& Wienland, J.A. (2008). A survey of registered nurses' readiness for evidence-based practice: a multidisciplinary project. Journal of Hospital Librarianship, $8(4)$, 440-448.

Bellamy, J. L., Bledsoe, S. E., \& Traube, D. (2006). The current state of evidence based practice in social work: A review of the literature and qualitative analysis of expert interviews. Journal of Evidence-Based Social Work, 3, 23-48.

Bellamy, J. L., Bledsoe, S. E., Mullen, E. J., Fang, L., \& Manuel, J. L. (2008). Agency-university partnership for evidence-based practice in social work. Journal of Social Work Education, 44(3), 55-75.

Berliner, D. C. (1990). If the metaphor fits, why not wear it? The teacher as executive. Theory into practice, 29(2), 85-93.

Bilsker, D., \& Goldner, E. (2004). Teaching evidence-based practice: overcoming barriers. Brief Treatment and Crisis Intervention, 4, 271-275.

Boehm, W. W. (1958). The nature of social work. Social Work, 3(2), 10-18.

Booth, S.H., Booth, A., \& Falzon, L. (2003). The need for information and research skills training to support evidence-based social case: a literature review and survey. Learning in Health and Social Care, 2(4), 191-201.

Bureau of Labor Statistics. (2014). Occupational outlook handbook: Registered nurses. Retrieved from http://www.bls.gov/ooh/healthcare/registered-nurses.htm

Burkhardt, H., \& Schoenfeld, A. H. (2003). Improving educational research: Toward a more useful, more influential, and better-funded enterprise. Educational Researcher, 32(9), 3-14.

Center for Workforce Studies. (2006). Assuring the sufficiency of a frontline workforce: A national study of licensed social workers. Washington, DC: National Association of Social Workers.

Cochran-Smith, M., \& Lytle, S. L. (1999). Relationships of knowledge and practice: Teacher learning in communities. Review of research in education, 24(1), 249-305.

Cohen, D. K. (1990). A revolution in one classroom: The case of Mrs. Oublier. Educational Evaluation and Policy Analysis, 12(3), 311-329.

Cohen, D. K. (2011). Teaching and its predicaments. Cambridge, MA: Harvard University Press.

Council on Social Work Education. (2008). Educational policy and accreditation standards. Retrieved from http://www.cswe.org/File.aspx?id=41861 
Edmondson, A.C., Bohmer, R.M., \& Pisano, G.P. (2001). Disrupted routines: Team learning and new technology implementation in hospitals. Administrative Sciences Quarterly, 46, 685-716.

Etzioni, A. (1969). The semi-professions and their organization: Teachers, nurses, social workers. New York, NY: Free Press.

Fisher, A., \& Fonteyn, M. (1995). An exploration of an innovative methodological approach for examining nurses' heuristic use in clinical practice. Research and Theory for Nursing Practice, 9(3), 263-276.

Gibbs, L. E. (2003). Evidence-based practice for the helping professions: A practical guide with integrated multimedia. Pacific Grove, CA: Brooks/Cole-Thompson.

Grinnell, R. M. Jr. \& Unrau, Y. A. (2010). Social work research and evaluation: Foundations of evidencebased practice (9th ed.). New York, NY: Oxford University Press.

Guskey, T. R. (2000). Evaluating professional development. Thousand Oaks, CA: Corwin.

Hammersley, M. (1997). Educational research and teaching: A response to David Hargreaves' TTA lecture. British Education Research Journal, 23(2), 141-161.

Heggen, K. (2008). Social workers, teachers and nurses-from college to professional work. Journal of Education and Work, 21(3), 217-231.

Hill, H. C. (2009). Fixing teacher professional development. Phi Delta Kappan, 90(7), 470-476. Ingersoll, R. M. (2003). Who controls teachers' work? Cambridge, MA: Harvard University Press.

Ingersoll, R. M., \& Perda, D. (2008). The status of teaching as a profession. In J. Ballantine \& J. Spade (Eds.), Schools and society: A sociological approach to education (pp. 106-118). Los Angeles, CA: Pine Forge Press.

Jenny, J., \& Logan, J. (1992). Knowing the patient: one aspect of clinical knowledge. Journal of Nursing Scholarship, 24(4), 254-258.

Jensen, J. M. (2007). Evidence-based practice and the reform of social work education: A response to Gambrill and Howard and Allen-Meares. Research on Social Work Practice, 17, $561-568$.

Kaestle, C. (1993). The awful reputation of education research. Educational Researcher, 22(1), 2331.

Kennedy, M. M. (1997). The connection between research and practice. Educational Researcher, 26(7), 4-12.

Krom, Z. R., Batten, J., \& Bautista, C. (2010). A unique collaborative nursing evidence-based practice initiative using the Iowa model: A clinical nurse specialist, a health science librarian, and a staff nurse's success story. Clinical Nurse Specialist, 24(2), 54-59.

Labaree, D. F. (1992). Power, knowledge, and the rationalization of teaching: A genealogy of the movement to professionalize teaching. Harvard Educational Review, 62(2), 123-155.

Labaree, D. F. (2000). On the nature of teaching and teacher education difficult practices that look easy. Journal of Teacher Education, 51(3), 228-233.

Lipsky, M. (1980). Street-level bureaucracy: Dilemmas of the individual in public services. New York, NY: Russell Sage Foundation.

Lizarondo, L. M., Grimmer-Somers, K., Kumar, S., \& Crockett, A. (2012). Does journal club membership improve research evidence uptake in different allied health disciplines: A pre-post study. BMC Research Notes, 5(1), 588.

Lundahl, B.W. (2008). Teaching research methodology through active learning. Journal of Teaching in Social Work, 28(1), 273-288. 
Majid, S., Foo, S., Luyt, B., Zhang, X., Theng, Y. L., Chang, Y. K., \& Mokhtar, I. A. (2011). Adopting evidence-based practice in clinical decision making: Nurses' perceptions, knowledge, and barriers. Journal of the Medical Library Association: JMLA, 99(3), 229.

Maxwell, B. (2015). Teacher as "professional" as metaphor: What it highlights and what it hides. Journal of Philosophy of Education, 49(1), 86-106.

May, R. (1939). The art of counseling. New York, NY: Gardner Press.

McCaughan, D., Thompson, C., Cullum, N., Sheldon, T. A., \& Thompson, D. R. (2002). Acute care nurses' perceptions of barriers to using research information in clinical decisionmaking. Journal of Advanced Nursing, 39(1), 46-60.

McNeill, T. (2006). Evidence-based practice in an age of relativism: Toward a model for practice. Social Work, 51, 147-156.

Melnyk, B. M., Fineout-Overholt, F., Feinstein, N. F., Sadler, L. S., \& Green-Hernandez, C. (2008). Nurse practitioner educators' perceived knowledge, beliefs, and teaching strategies reading evidence-based practice: Implications for accelerating the integration of evidence-based practice into graduate programs. Journal of Professional Nursing, 20(1), 713.

Miller, S. R., Drill, K. \& Behrstock, E. (2010). Meeting teachers half way: Making educational research relevant to teachers. Phi Delta Kappan, 91(7), 32.

Morgenshtern, M., Freymond, N., Agyapong, S., \& Greeson, C. (2011). Graduate social work students' attitudes toward research: Problems and prospects. Journal of Teaching in Social Work, 31, 552-568.

Mullen, E. J. \& Bacon, W. B. (2004). Implementation of practice guidelines and evidence-based treatment: A survey of psychiatrists, psychologists, and social workers. In A. R. Roberts \& K. Yeager (Eds.), Evidence-based practice manual: Research and outcome measures in health and buman services (pp. 210-218). New York, NY: Oxford University Press.

Mullen, E. J., Bledsoe, S. E., \& Bellamy, J. L. (2008). Implementing evidence-based social work practice. Research on Social Work Practice, 18(4), 426-436.

National Association of Social Workers Delegate Assembly. (2008). Code of ethics. Washington, DC: National Association of Social Workers.

National Education Association. (2010). Status of the American public school teacher 2005-2006. Washington, DC: NEA.

Neville, K. S., Sherman, R. H., \& Cohen, C. E. (2005). Preparing and training professionals. Comparing education to six other fields. Finance Project. http://files.eric.ed.gov/fulltext/ED485648.pdf

Paramonczyk, A. (2005). Barriers to implementing research in clinical practice. Canadian Nurse 101(3), 12-15.

Popple, P. R. (1985). The social work profession: A reconceptualization. The Social Service Review, 59(4), 560-577.

Pravikoff, D.S., Pierce, S., \& Tanner, A. (2003). Are nurses ready for evidence-based practice? American Journal of Nursing, 103(5), 40-51.

Roberts, A. R., \& Greene, G. J. (2002). Social workers' desk reference. New York, NY: Oxford University Press.

Rubin, A., \& Babbie, E. (2011). Research methods for social work (7th ed.). Pacific Grove, CA: Brooks/Cole.

Rubin, A., \& Parrish, D. (2007). Challenges to the future of evidence-based practice in social work education. Journal of Social Work Education, 43(3), 405-428.

Schneider, J. (2014). From the ivory tower to the schoolhouse: How scholarship becomes common knowledge in education. Cambridge, MA: Harvard Education Press. 
Sheekey, A.D. (2013, July 9). Why we need state-based education R \& D. Education Week, 32(36) $32-33$.

Sheldon, B., \& Chilvers, R. (2002). An empirical study of the obstacles to evidence-based practice. Social Work \& Social Sciences Review, 10(1), 6-26.

Shulman, L. S. (2005). Signature pedagogies in the professions. Daedalus, 134(3), 52-59.

Tannery, N. H., Wessel, C. B., Epstein, B. A., \& Gadd, C. S. (2007). Hospital nurses' use of knowledge-based information sources. Nursing Outlook, 55(1), 15-19.

Titler, M. G., Kleiber, C., Steelman, V., Rakel, B., Budreau, G., Everett, L. Q., Buckwalter, K. C., Tripp-Reimer, T., \& Goode, C. (2001). The Iowa model of evidence-based practice to promote quality care. Critical Care Nursing Clinics of North America, 13(1), 497-509.

U.S. Department of Labor. (2005). Quick facts on registered nurses. Retrieved from http://www.dol.gov/wb/factsheets/Qf-nursing-06.htm

Welker, R. (1991). Expertise and the teacher as expert: Rethinking a questionable metaphor. American Educational Research Journal, 28(1), 19-35.

Wolk, R. (2007). Education research could improve schools, but probably won't. Education Week, $26(42), 38-39$.

Young, K. M. (2003). Where is the evidence? "Evidence-based practice" is not a reality for most nurses. American Journal of Nursing, 103(10), 11.

Zeuli, J. S. (1994). How do teachers understand research when they read it? Teaching and Teacher Education, 10(1), 39-55. 
About the Author

Jack Schneider

College of the Holy Cross

jschneid@,holycross.edu

Jack Schneider is an assistant professor of education at the College of the Holy Cross and the author of two books. He is currently writing a book about the way Americans gauge the quality

of their public schools.

\title{
About the Co-Guest Editors
}

Dr. Amanda Cooper
Queen's University
amanda.cooper@queensu.ca

Amanda Cooper is a faculty member at Queen's University, building a program of research focusing on Knowledge Mobilization in education. She is a chaser of the ever-elusive research impact and believes that collaborations among diverse stakeholders is the best way to move the system forward.

Samantha Shewchuk

Queen's University

s.shewchuk@queensu.ca

Samantha Shewchuk is an elementary school teacher and a doctoral student in the Faculty of Education at Queen's University. Her research explores knowledge mobilization at the intersection of the education and child welfare sectors; more specifically, how outcomes for abused children can be improved by increasing research use in these sectors. She is the program manager of Dr. Amanda Cooper's RIPPLE program, Research Informing Policy Practice and Leadership in Education (www.ripplenetwork.ca)

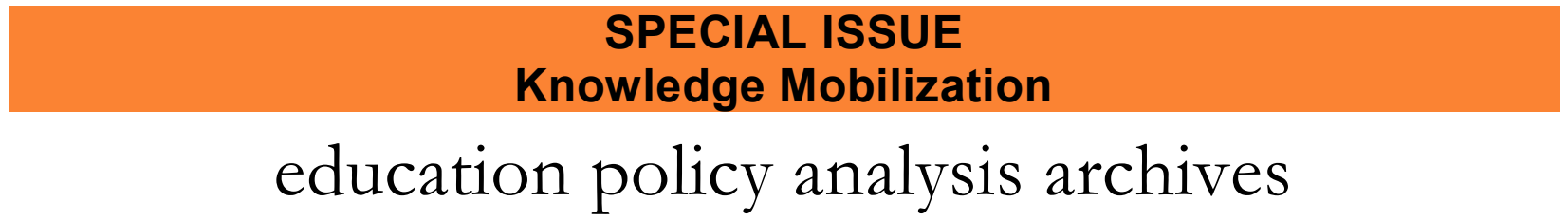

Volume 23 Number 119

December 7, 2015

ISSN 1068-2341

\begin{abstract}
(c)
SOMAERIGHISRESERVED Readers are free to copy, display, and distribute this article, as long as the work is attributed to the author(s) and Education Policy Analysis Archives, it is distributed for noncommercial purposes only, and no alteration or transformation is made in the work. More details of this Creative Commons license are available at http://creativecommons.org/licenses/by-nc-sa/3.0/. All other uses must be approved by the author(s) or EPAA. EPAA is published by the Mary Lou Fulton Institute and Graduate School of Education at Arizona State University Articles are indexed in CIRC (Clasificación Integrada de
\end{abstract}


Revistas Científicas, Spain), DIALNET (Spain), Directory of Open Access Journals, EBSCO

Education Research Complete, ERIC, Education Full Text (H.W. Wilson), QUALIS A2 (Brazil), SCImago Journal Rank; SCOPUS, SOCOLAR (China).

Please contribute commentaries at http://epaa.info/wordpress/ and send errata notes to Gustavo E. Fischman fischman@asu.edu

Join EPAA's Facebook community at https://www.facebook.com/EPAAAAPE and Twitter feed@epaa_aape. 


\section{education policy analysis archives editorial board}

Editor Gustavo E. Fischman (Arizona State University)

Associate Editors: Audrey Amrein-Beardsley (Arizona State University), Rick Mintrop, (University of California, Berkeley) Jeanne M. Powers (Arizona State University)

Jessica Allen University of Colorado, Boulder

Gary Anderson New York University

Michael W. Apple University of Wisconsin, Madison

Angela Arzubiaga Arizona State University

David C. Berliner Arizona State University

Robert Bickel Marshall University

Henry Braun Boston College

Eric Camburn University of Wisconsin, Madison

Wendy C. Chi* University of Colorado, Boulder

Casey Cobb University of Connecticut

Arnold Danzig Arizona State University

Antonia Darder University of Illinois, UrbanaChampaign

Linda Darling-Hammond Stanford University

Chad d'Entremont Strategies for Children

John Diamond Harvard University

Tara Donahue Learning Point Associates

Sherman Dorn University of South Florida

Christopher Joseph Frey Bowling Green State University

Melissa Lynn Freeman* Adams State College

Amy Garrett Dikkers University of Minnesota

Gene V Glass Arizona State University

Ronald Glass University of California, Santa Cruz

Harvey Goldstein Bristol University

Jacob P. K. Gross Indiana University

Eric M. Haas WestEd

Kimberly Joy Howard* University of Southern California

Aimee Howley Ohio University

Craig Howley Ohio University

Steve Klees University of Maryland

Jaekyung Lee SUNY Buffalo
Christopher Lubienski University of Illinois, UrbanaChampaign

Sarah Lubienski University of Illinois, UrbanaChampaign

Samuel R. Lucas University of California, Berkeley

Maria Martinez-Coslo University of Texas, Arlington

William Mathis University of Colorado, Boulder

Tristan McCowan Institute of Education, London

Heinrich Mintrop University of California, Berkeley

Michele S. Moses University of Colorado, Boulder

Julianne Moss University of Melbourne

Sharon Nichols University of Texas, San Antonio

Noga O'Connor University of Iowa

João Paraskveva University of Massachusetts, Dartmouth

Laurence Parker University of Illinois, UrbanaChampaign

Susan L. Robertson Bristol University

John Rogers University of California, Los Angeles

A. G. Rud Purdue University

Felicia C. Sanders The Pennsylvania State University

Janelle Scott University of California, Berkeley

Kimberly Scott Arizona State University

Dorothy Shipps Baruch College/CUNY

Maria Teresa Tatto Michigan State University

Larisa Warhol University of Connecticut

Cally Waite Social Science Research Council

John Weathers University of Colorado, Colorado Springs

Kevin Welner University of Colorado, Boulder

Ed Wiley University of Colorado, Boulder

Terrence G. Wiley Arizona State University

John Willinsky Stanford University

Kyo Yamashiro University of California, Los Angeles

* Members of the New Scholars Board 


\section{archivos analíticos de políticas educativas consejo editorial}

Editor: Gustavo E. Fischman (Arizona State University)

Editores. Asociados Alejandro Canales (UNAM) y Jesús Romero Morante (Universidad de Cantabria)

Armando Alcántara Santuario Instituto de

Investigaciones sobre la Universidad y la Educación, UNAM México

Claudio Almonacid Universidad Metropolitana de Ciencias de la Educación, Chile

Pilar Arnaiz Sánchez Universidad de Murcia, España

Xavier Besalú Costa Universitat de Girona, España

Jose Joaquin Brunner Universidad Diego Portales, Chile

Damián Canales Sánchez Instituto Nacional para la Evaluación de la Educación, México

María Caridad García Universidad Católica del Norte, Chile

Raimundo Cuesta Fernández IES Fray Luis de León, España

Marco Antonio Delgado Fuentes Universidad Iberoamericana, México

Inés Dussel FLACSO, Argentina

Rafael Feito Alonso Universidad Complutense de Madrid, España

Pedro Flores Crespo Universidad Iberoamericana, México

Verónica García Martínez Universidad Juárez Autónoma de Tabasco, México

Francisco F. García Pérez Universidad de Sevilla, España

Edna Luna Serrano Universidad Autónoma de Baja California, México

Alma Maldonado Departamento de Investigaciones Educativas, Centro de Investigación y de Estudios Avanzados, México

Alejandro Márquez Jiménez Instituto de Investigaciones sobre la Universidad y la Educación, UNAM México

José Felipe Martínez Fernández University of California Los Angeles, USA
Fanni Muñoz Pontificia Universidad Católica de Perú

Imanol Ordorika Instituto de Investigaciones Economicas - UNAM, México

Maria Cristina Parra Sandoval Universidad de Zulia, Venezuela

Miguel A. Pereyra Universidad de Granada, España

Monica Pini Universidad Nacional de San Martín, Argentina

Paula Razquin UNESCO, Francia

Ignacio Rivas Flores Universidad de Málaga, España

Daniel Schugurensky Universidad de Toronto-Ontario Institute of Studies in Education, Canadá

Orlando Pulido Chaves Universidad Pedagógica Nacional, Colombia

José Gregorio Rodríguez Universidad Nacional de Colombia

Miriam Rodríguez Vargas Universidad Autónoma de Tamaulipas, México

Mario Rueda Beltrán Instituto de Investigaciones sobre la Universidad y la Educación, UNAM México

José Luis San Fabián Maroto Universidad de Oviedo, España

Yengny Marisol Silva Laya Universidad Iberoamericana, México

Aida Terrón Bañuelos Universidad de Oviedo, España

Jurjo Torres Santomé Universidad de la Coruña, España

Antoni Verger Planells University of Amsterdam, Holanda

Mario Yapu Universidad Para la Investigación Estratégica, Bolivia 


\section{arquivos analíticos de políticas educativas conselho editorial}

Editor: Gustavo E. Fischman (Arizona State University) Editores Associados: Rosa Maria Bueno Fisher e Luis A. Gandin

(Universidade Federal do Rio Grande do Sul)

Dalila Andrade de Oliveira Universidade Federal de Minas Gerais, Brasil

Paulo Carrano Universidade Federal Fluminense, Brasil

Alicia Maria Catalano de Bonamino Pontificia Universidade Católica-Rio, Brasil

Fabiana de Amorim Marcello Universidade Luterana do Brasil, Canoas, Brasil

Alexandre Fernandez Vaz Universidade Federal de Santa Catarina, Brasil

Gaudêncio Frigotto Universidade do Estado do Rio de Janeiro, Brasil

Alfredo M Gomes Universidade Federal de Pernambuco, Brasil

Petronilha Beatriz Gonçalves e Silva Universidade Federal de São Carlos, Brasil

Nadja Herman Pontificia Universidade Católica -Rio Grande do Sul, Brasil

José Machado Pais Instituto de Ciências Sociais da Universidade de Lisboa, Portugal

Wenceslao Machado de Oliveira Jr. Universidade Estadual de Campinas, Brasil
Jefferson Mainardes Universidade Estadual de Ponta Grossa, Brasil

Luciano Mendes de Faria Filho Universidade Federal de Minas Gerais, Brasil

Lia Raquel Moreira Oliveira Universidade do Minho, Portugal

Belmira Oliveira Bueno Universidade de São Paulo, Brasil

António Teodoro Universidade Lusófona, Portugal

Pia L. Wong California State University Sacramento, U.S.A

Sandra Regina Sales Universidade Federal Rural do Rio de Janeiro, Brasil

Elba Siqueira Sá Barreto Fundação Carlos Chagas, Brasil

Manuela Terrasêca Universidade do Porto, Portugal

Robert Verhine Universidade Federal da Bahia, Brasil

Antônio A. S. Zuin Universidade Federal de São Carlos, Brasil 